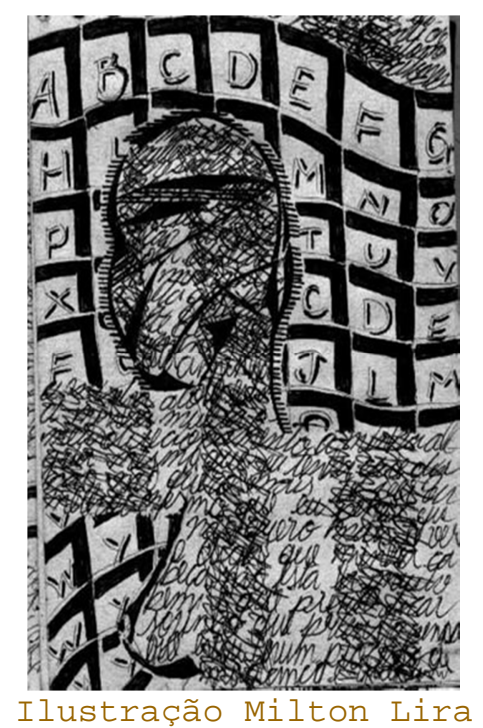

\title{
O médium, a mediação e o imediato - livro, cinema e televisão em Beatriz Sarlo
}

\section{Georg Otte, Ianá Costa de Andrade}

Georg Otte é professor de Língua e Literatura Alemãs na Faculdade de Letras/UFMG.

Ianá Costa de Andrade foi bolsista de Iniciação Científica pelo CNPq.

\section{Resumo}

Partindo de algumas reflexões fundamentais em torno dos conceitos "medium" e "gravação", da comunicação simultânea "no espaço" e da comunicação sucessiva "no tempo" e da diferença entre a oralidade e a escrita, o presente texto analisa as idéias de Beatriz Sarlo sobre o livro, o cinema e a televisão enquanto portadores de diversas estéticas da comunicação.

Palavras-chave: comunicação, gravação, estética.

Durante o Simpósio Internacional Comunicação e Experiência Estética, realizado em setembro de 2004 em Belo Horizonte, o prof. Norval Baitello Jr. "pediu licença" às organizações espíritas para poder usar o termo médium numa acepção 
puramente comunicativa, uma vez que, no Brasil, seu uso é praticamente restrito ao âmbito espírita. Pela sua origem latina e pelo uso do termo latim em inglês ou alemão, no entanto, medium significa "meio", podendo designar tanto o meio em que se vive - o meio ambiente, por exemplo - quanto o meio que o ser humano usa para conseguir uma determinada finalidade, ou seja, o instrumento. Mesmo se o "meio de comunicação" parece apontar claramente para o último uso, isto é, enquanto ferramenta, o outro não deixa de ter uma grande importância também para essa área, pois o meio, o ambiente em que as pessoas se comunicam é decisivo para o processo de comunicação.

Fala-se também em mídia, provavelmente uma adaptação da pronúncia do inglês media, que nada mais é do que o plural do já mencionado medium em latim. Mas esse plural é usado para fazer referência aos meios eletrônicos de comunicação de massa ("mass-mídia"). Em outras palavras: não há um termo de uso fácil para o meio de comunicação individual, o papel que se usa para fazer uma anotação, a areia na praia que serve para esboçar um itinerário ou o próprio rosto que pode expressar uma série de coisas. O papel, a areia e o rosto são ferramentas - portadores mais ou menos duráveis de informações - que não deixam de ser "médiuns" por serem usados em situações cotidianas e para finalidades mais ou menos triviais.

Mas não é por acaso que o espiritismo monopolizou o termo médium no Brasil, e talvez esse fato, inicialmente visto como um obstáculo para a teoria da comunicação, tenha também seu lado elucidativo. Pois esse médium espírita é um meio de comunicação entre, digamos (pedindo desculpas pelo nosso desconhecimento na matéria), duas esferas distantes, intermediando-as à maneira da mídia eletrônica que também se empenha em possibilitar a comunicação entre esferas distantes. Por trás do médium espírita há um processo de comunicação não muito diferente do modelo clássico de Shannon e Weaver (1), com suas instâncias emissor, canal e receptor. Seguindo esse modelo, ele também desempenharia o papel de "canal", passando para os receptores presentes mensagens emitidas de outra esfera. Lembramos que a palavra "canal" tornou-se sinônimo de uma estação de rádio ou televisão.

Cabe lembrar também que, a rigor, o uso do termo "comunicação" não envolve necessariamente a troca de informações, mas significa, antes de mais nada, a abertura de um canal, à maneira de duas salas que "se comunicam" por meio de uma passagem entre elas(2), sendo o fluxo das informações apenas uma possível conseqüência dessa abertura. Em primeiro lugar, portanto, a capacidade excepcional do médium espírita consistiria na possibilidade de "fazer contato", de abrir um 
canal - quase - direto com outro mundo e, só num segundo momento, de receber e, eventualmente, transcrever mensagens.

A televisão enquanto médium (lato sensu) também providencia um acesso aparentemente direto, i-mediato, a outra esfera, sendo que, evidentemente, há uma série de mecanismos intercalados que influenciam a mediação de informações. Esse acesso é imediato, no sentido temporal, como no caso de uma transmissão ao vivo, mas não deixa por isso de passar por uma série de filtragens que manipulam a transmissão de um acontecimento transmitido.

Portanto, além de mediadores, os meios de comunicação são também mediados. Mesmo no caso da transmissão ao vivo de televisão, a imagem projetada, que funciona como mediação imediata (instantânea) de um acontecimento qualquer e o telespectador, é também mediada (não imediata), pois, escolhida, focada, iluminada ou não, apresentada com ou sem fundo musical, cujo tempo de transmissão independe da duração real do evento etc. Aliás, uma das críticas mais freqüentes à mídia eletrônica é exatamente essa ilusão de ela ser mais "verdadeira" por não haver nenhuma defasagem entre o momento da produção e o da recepção, veiculando inclusive a produção com todas as suas possíveis falhas. (3)

Nem toda transmissão ao vivo necessariamente é acompanhada por uma gravação, isto é, por um registro técnico posteriormente reprodutível. Uma vez que se trata, em primeiro lugar, de "abrir o canal" entre o evento transmitido e o receptor, a gravação dessa transmissão é um processo secundário. Na prática, aproveita-se a transmissão, por assim dizer, para fazer também uma gravação, que poderá ser reproduzida mais tarde (re-transmitida), servindo ocasionalmente de documento ou de testemunho - ou então a fins comerciais.

Dando, mais uma vez, livre curso ao nosso pendor filológico, cabe uma observação sobre o fenômeno da gravação, pois ele remonta às épocas primitivas da escrita quando os textos eram "gravados", isto é, entalhados em algum material resistente. 0 termo se manteve - pelo menos na língua portuguesa - como metáfora para designar registros técnicos, tanto sonoros quanto visuais, que já não exigem mais nenhum esforço físico por parte do técnico da gravação, uma vez que se trata, fisicamente, apenas de processos foto-químicos ou fotoeletrônicos. O que importa é que, em ambos os sentidos, a gravação pressupõe o uso de um "médium", de um portador da informação; "gravação" não significa outra coisa senão a existência de um suporte material responsável pela transmissão e conservação de uma informação imaterial. (4) 
Talvez a diferença entre a abertura de um canal de comunicação e a gravação fique mais clara através do exemplo de uma câmera de vídeo instalada numa agência bancária: por um lado, essa câmera transmite os acontecimentos ao vivo para uma central onde um observador fica atento para qualquer anormalidade e aciona o sistema de segurança na eventualidade de um assalto. Ao mesmo tempo, todo o cenário transmitido é registrado através de uma gravação que servirá de testemunho tanto para uma possível investigação criminal quanto para o decorrente processo penal. No primeiro caso, é a necessidade de uma reação instantânea que exige a transmissão simultânea, no segundo, trata-se da reconstrução da mesma cena. A gravação já não é mais a "janela" que possibilita acompanhar os acontecimentos "ao vivo", mas é o testemunho que serve de base para uma posterior investigação.

Distinguir entre a comunicação direta através de um canal aberto (a transmissão ao vivo), por um lado, e a comunicação indireta (através de uma gravação) é essencial por implicar em modos diferentes de representação e de percepção, ou seja, em diferenças estéticas importantes. (5) Como em qualquer análise estética, considerações sobre 0 tempo e 0 espaço são essenciais para chegar a uma compreensão mais diferenciada dos fenômenos em questão.

Partindo do pressuposto de a comunicação, tanto no sentido primário (abertura de um canal), quanto no sentido secundário (transmissão de informações), implicar na transposição de barreiras de qualquer natureza, pode-se dizer que a transmissão ao vivo supera distâncias no espaço e a gravação distâncias no tempo, sendo que cada uma das duas categorias evoca sua determinação pela outra: a comunicação "espacial" da transmissão ao vivo, em termos temporais, é simultânea, ao passo que a "temporal", na qual a recepção é posterior à produção, necessariamente tem que ter sido gravada em algum material, em algum portador da informação que, usando uma tautologia, se localiza no espaço. Mesmo na era da reprodutibilidade virtual, as informações "soft" são vinculadas a algum material "hard" e perdem seu valor quando não são mais localizáveis, seja no hard-disc, seja no espaço "virtual" de um provedor que, em última instância, sempre tem uma base material. Sendo assim, o livro também é virtual, e só deixa de sê-lo quando lido, como ainda será exposto.

$\mathrm{Na}$ verdade, os modernos meios de comunicação são, com algumas ressalvas, uma ampliação da "velha" diferença entre a oralidade e a escrita, uma vez que a transmissão ao vivo corresponde à primeira e a gravação à segunda. A comunicação oral é simultânea e ocorre dentro de um determinado "meio" enquanto ambiente ou canal aberto, compartilhado por emissor e 
receptor -, ao passo que a escrita delega a mensagem ao papel enquanto portador da informação, que serve de meio no sentido instrumental; tanto a escrita quanto o registro em disco são gravações.(6) Voltamos portanto à já mencionada ambigüidade relacionada com o termo "meio de comunicação", que tanto pode se referir ao meio no sentido de um espaço (ambiente, canal) compartilhado pelos participantes, quanto ao meio no sentido de instrumento. (7)

Se a gravação é capaz de superar distâncias no tempo, vale também o inverso, ou seja, qualquer tentativa de comunicação com o passado necessita da gravação, seja ela recente como no nosso exemplo do assalto a um banco e sua investigação subsequiente, seja ela remota, como no caso dos achados arqueológicos de culturas extintas e sua decifração após alguns milênios. Nos dois exemplos ocorre uma investigação, ou seja, uma busca de vestígios no intuito de se chegar a algum tipo de esclarecimento sobre algo desconhecido ou mal conhecido. Nos dois casos, trata-se de documentos capazes de testemunhar um evento recente.

Evidentemente, uma gravação de vídeo é um testemunho quase infalível e chamá-la apenas de "vestígio" não corresponde à realidade da investigação criminal, para a qual uma tal gravação representa muito mais do que uma simples "pista". No entanto, a gravação de um assalto não é um assalto, mas a sua representação, podendo conter algumas imprecisões.(8) Haveria portanto necessidade de uma maior diferenciação semiótica entre representações consideradas "ricas", como textos e imagens, e "pobres", isto é, qualquer objeto que, por mais simples que seja, tem as marcas de algum evento do passado gravadas em si mesmo e as conservou até o presente, as re(a) presenta.

Voltando à questão da objetividade, cabe ressaltar que tanto a investigação criminalística e a historiografia, por um lado, quanto as produções cinematográficas e literárias, por outro, envolvem questões de imparcialidade e de parcialidade. Se a pretensa imparcialidade das primeiras sempre merece um olhar crítico, a parcialidade das segundas é, de certa maneira, assumida pelos envolvidos. A investigação e 0 acesso às "verdades" passam por processos como construção e escolha. Como a atividade histórica, que é mediada por um sujeito que, "objetivamente", deverá adotar uma determinada linha teórica (e ainda que decida não "se prender" a nenhuma, também estará fazendo uma escolha), delimitar os temas, eleger os fatos a serem abordados (rejeitando, automaticamente, outros) e, por fim, optar pelas estratégias narrativas e didáticas mais adequadas às suas descrições e interpretações. Até a reconstrução de um crime, para retomar o âmbito criminalístico, é uma construção. 
Ambos, a investigação criminalística e a histórica dividem a preocupação epistemológica em reconstruir eventos - inclusive os crimes - de um passado mais ou menos remoto para conseguir um conhecimento melhor sobre ele, e a preocupação ética de resgatar e retrabalhar um passado "mal resolvido", um passado que cobra do presente algum tipo de satisfação, ou, para usar - vocabulário teológico das Teses de Benjamin, de "redenção". É dessa cobrança que trata também o ensaio de Beatriz Sarlo, "A história contra o esquecimento", sobre o filme shoah de Claude Lanzmann. Vale lembrar que não se trata tanto de ampliar o conhecimento sobre o holocausto, mas de impedir que ele acabe de fazer parte do nosso presente. Diferentemente do trabalho historiográfico, o filme não tem a pretensão de apresentar fatos novos sobre o acontecido, mas apenas recortes e fragmentos, ou seja, vestígios que apenas sugerem ao espectador ou ao leitor uma idéia da totalidade dos eventos.

Se não são fatos novos, o filme de Lanzmann fornece aspectos novos de um acontecimento já bastante analisado. É nesse sentido que devemos entender o ganho de "saber" proporcionado por Shoah:[Lanzmann] sabe que sabemos, mas também acredita que não sabemos o bastante. Ou, melhor dizendo, que sabemos do horror da Solução Final, mas não nos inteiramos suficientemente de sua mecânica e de sua administração. (9)

Uma coisa é "saber" que seis milhões de judeus foram mortos nos campos de concentração, outra coisa é fazer os espectadores do presente se preocuparem com esse saber. Pelo grande número de obras documentárias e ficcionais sobre o assunto, a grande maioria das pessoas fica "sabendo" do que houve. Lanzmann, no entanto, não se contenta com esse saber, muito menos com produções cinematográficas do gênero A lista de Schindler que, ao invés de levantar novos questionamentos, tranquilizam os espectadores focalizando o caso excepcional do salvamento de uma "lista" de judeus.

Shoah, no entanto, não difere apenas da ficção hollywoodiana, mas também dos documentários habituais. Ele abre mão das fotografias de corpos esqueléticos, de cadáveres amontoados, de crianças com estrelas amarelas em seus casacos. Sustenta, implicitamente, que esses documentos já deram tudo de si. Foram vistos milhares de vezes e, se não perderam sua verdade documental, foram nos acostumando a seu horror. Lanzmann constrói shoah com outras imagens, que ainda não haviam revelado os significados de que são portadoras ou, para fazer jus à estratégia do cineasta, o significado que delas consegue extrair. (10) 
Paradoxalmente, a repetição de documentos sempre iguais, por mais chocantes que sejam, favorece tanto o esquecimento quanto a falta de documentos; acabam sendo "arquivados" mentalmente, ou seja, continuam existindo fisicamente, mas produzem pouco ou nenhum impacto no receptor do presente. Apesar de suas dez horas de duração, o filme de Lanzmann não procura veicular o máximo possível de informações, mas se limita a apresentar imagens aparentemente triviais da paisagem em volta dos campos de concentração, trechos de entrevistas com os sobreviventes (judeus e nazistas) e, principalmente, muitos detalhes como os trilhos dos trens e "algumas pedras que foram pisadas pelos condenados em seu caminho rumo à câmara de gás" (p. 36). Para não "arquivar" o holocausto, Shoah lança mão dos "restos materiais" (p. 36) que, enquanto "ruínas", como diria Benjamin, são portadores de que não apenas carregavam literalmente o peso dos trens e dos condenados, mas que, enquanto objetos mortos, paradoxalmente, "sobreviveram" ao extermínio dos vivos e servem como transmissores do passado para o presente. Lanzmann troca as imagens fotográficas e suas evidências por testemunhos "pobres" que não provam nada (e até poderiam ser "falsos"), mas que, como as testemunhas vivas, "assistiram" aos acontecimentos que se gravaram neles, carregando os vestígios que conduzem diretamente ao passado. São testemunhas que não envelhecem nem morrem, que não têm falhas de memória e não fogem do passado, mas insistem em representá-lo, em presentificá10: "Os detalhes lutam pela presentificação do passado para tornar presentes os valores que, nesse passado, foram atacados por uns e defendidos por outros" (p. 42). O filme de Lanzmann é a gravação de uma gravação: grava os elementos nos quais se gravaram os vestígios do passado. Se as fotos conhecidas dos campos de concentração carregam ao mesmo tempo os traços do seu envelhecimento, o "hardware" dos trilhos e das pedras mantém as marcas inscritas nele, mesmo se não são visíveis a olho nu. Mas não há necessidade de um zoom microscópico, nem um laboratório de investigação criminal para mostrar que essa marcas realmente existem. O que importa é que os trilhos e as pedras são os mesmos, que são eles que permitem uma localização do passado, passado este que não passa enquanto o lugar for mantido inalterado.(11)

A filmagem de trilhos e caminhos de pedra ganham ainda um "efeito especial" - bem diferente daqueles de Spielberg - pelo fato de sua função primária estar na comunicação espacial, de estarem responsáveis pela comunicação (na acepção primária) entre dois lugares distantes. O fato de o outro lugar ser a câmera de gás e de esses caminhos levarem para o nada, para a morte, certamente aumenta o impacto dessas imagens. Se os trilhos e as pedras evocam e desmentem ao mesmo tempo a sua função comunicativa no plano espacial, o mesmo acontece no temporal: o filme de Lanzmann evoca a comunicação entre o presente e o passado através dos vestígios materiais, mas evidencia ao mesmo tempo o fracasso da comunicação temporal, uma vez que o passado não tem como responder, como coresponder aos apelos do presente. Trata-se de testemunhas mudas não apenas por não falarem, mas também pelo fato de seu caráter de vestígio não se confirmarem, pois essas pistas da história levam ao nada. A pedra, símbolo da mudez em várias culturas, paradoxalmente passa a ser a representação adequada do holocausto, uma vez que ela diz o indizível. 
Experiência semelhante se repete na entrevista com um sobrevivente do campo de concentração:

Lanzmann filma empurrado por uma fúria racional, uma espécie de paradoxo, se assim se preferir. Sua testemunha, que começa a recordar com força, sem lamentações, sem debilidades, no final esmorece. A luta registrada é entre o anseio de verdade e a necessidade de, a certa altura, afastar-se dessa verdade, abandoná-la como se abandona um território, não para esquecer, mas para passar, por ora (até quando?), a outro assunto. (12)

Lanzmann se afasta da verdade porque o território para o qual levam as pistas está vazio. Algo semelhante acontece nessa entrevista, na qual o depoimento do sobrevivente mal evoca o passado, que este passado sufoca o depoimento. Não se trata aqui apenas de um dos inúmeros casos já analisados pela traumatologia, mas também de mais uma testemunha muda. A insistência de Lanzmann em não parar a filmagem apesar dos pedidos da testemunha se explica, possivelmente, pela intenção de não apenas mostrar as respostas do passado, mas também a impossibilidade de completar essa resposta, deixando que "a câmera ainda o registra por mais alguns segundos, que parecem intermináveis. "Esses segundos são intermináveis, pois representam, presentificam a morte da qual a testemunha escapou por

pouco.

Comparando o filme de Lanzmann com A Lista de Schindler e baseando-se num artigo de Raúl Beceyro, Beatriz Sarlo aponta para o contraste entre a riqueza dos recursos cinematográficos e a pobreza simbólica no caso de Spielberg: "Spielberg demonstra o mesmo desinteresse de schindler com a dimensão simbólica da comunidade prática: os judeus de spielberg são pobres do ponto de vista religioso e simbólico." E, ainda conforme o artigo de Beceyro, "[...] a superprodução de Spielberg gastou seus milhões sem chegar a construir alguma materialidade de representação", enquanto a fita de Lanzmann apresenta a materialidade de uma operação de morte como problema histórico e também como problema narrativo de seu filme, construído sobre o rastreamento dos resíduos materiais dos campos de concentração, a leitura dos indícios fornecidos pelas ruínas de edifícios, pelo traçado dos trilhos e das estradas. (13)

"Benjaminiana confessa", Beatriz Sarlo enfatiza a importância da materialidade dos portadores da memória e a oposição entre sua aparente pobreza e efetiva riqueza. Querendo mostrar tudo, Spielberg empobrece ao mesmo tempo as possibilidades de "leitura", sendo que só pode haver leitura onde há símbolos (ou "indícios"). Os poucos "detalhes" de Lanzmann, ao contrário, tanto são portadores de vestígios, quanto são eles mesmos vestígios, fragmentos metonímicos de uma totalidade do 
passado, que não apenas comunicam algo ao espectador, mas são fragmentos, "ruínas" de um passado que dirige seus apelos às pessoas do presente para que estas o recomponham e "redimam", em analogia aos esforços do anjo da história das Teses de Benjamin. Essa recomposição pode ser impossível devido aos vazios deixados pelo passado, mas a própria frustração da tentativa impede ao mesmo tempo o esquecimento de uma maneira mais eficaz do que a riqueza de detalhes oferecida por Spielberg, detalhes estes que preenchem os vazios, mas, pela sua própria riqueza, encobrem o passado ao invés de recompô10.

Não se trata, portanto, de "saber" mais sobre o holocausto, como diz a autora quando reflete sobre as razões que levaram Lanzmann a filmar Shoah (p. 40). Spielberg e Lanzmann trabalham com o mesmo saber, mas o representam - ou presentificam - de maneira diferente. Provavelmente, Shoah não acrescenta nada (ou muito pouco) ao que já se sabe sobre o holocausto, mas "ilumina" - para usar outro termo benjaminiano, condizente, por cima, com as técnicas de cinema - o holocausto de outra maneira. O "materialismo" de Lanzmann, portanto, é uma opção estética e não epistemológica. Evidentemente, não seria difícil ampliar o campo semântico da palavra saber para o âmbito estético, ainda mais que saber e sabor são parentes etimológicos, parentesco este que, infelizmente, se perdeu nos nossos dias.

A diferenciação entre o plano epistemológico e estético é relevante, uma vez que o critério do primeiro é a verdade (histórica), enquanto o segundo não opera com a dicotomia verdadeiro/falso. Lanzmann e Spielberg não discutem a veracidade dos acontecimentos, questionada "apenas" por grupos neonazistas, mas oferecem, basicamente, "versões" bastante diferentes de uma mesma verdade. Provavelmente, Lanzmann, através do seu documentário, acrescenta alguns fatos, ou seja, documentos novos, capazes de ampliar o fundo de informações históricas, mas a diferença essencial entre os dois diretores está no plano da representação e da conseqüente percepção do holocausto, ou seja, no plano estético.

Contrariando a visão amplamente difundida da estética como a parte "ornamental" de uma obra ou o "toque pessoal" que um autor acrescenta ao "fato em si", cabe sublinhar que qualquer aspecto que diz respeito à composição ou à construção da obra, mesmo de um documentário, é de natureza estética. Uma vez que há consenso de que a própria história não é apenas reconstrução, mas também construção, o trabalho historiográfico também envolve aspectos estéticos. O risco da historiografia consiste justamente no fato de determinadas convenções na representação da história ganharem status de verdade e de assim se imporem à prática científica como um 
todo. Daí a importância da análise estética, pois é a partir dela que as convenções na percepção e na recepção dos fatos são desmascaradas como sendo apenas convenções, evidenciando que o discurso, inclusive o discurso científico, sempre poderia ser outro. A estética, portanto, ao invés de ser "perfumaria", é intrínseca a qualquer discurso, seja ele científico ou artístico.(14)

Por isso, seria equivocado ver no "materialismo" de Lanzmann um modo de representação "mais próximo dos fatos", um neorealismo que abre mão dos ingredientes subjetivistas do diretor. Muito pelo contrário: além de o procedimento de Lanzmann se aproximar mais de uma estética romântica stricto sensu, segundo a qual os objetos não são auto-suficientes, mas vestígios que sempre transcendem a si próprios apontando sempre para outra coisa, sua opção "materialista" é eminentemente estética.

Enquanto a mediação do passado e a decorrente comunicação com ele necessariamente passam pelos portadores enquanto intermediadores da informação, os modernos meios de comunicação se preocupam mais em superar as distâncias no espaço e em gerar uma comunicação simultânea. Uma outra diferença consiste no lugar do receptor: no caso dos portadores físicos da informação, o receptor costuma escolher entre uma oferta infinita de possibilidades de se comunicar com o passado, ao passo que, no caso das transmissões ao vivo, ele costuma se deixar surpreender pelos acontecimentos que acontecem em outro lugar e aos quais ele assiste muitas vezes simplesmente para se distrair.(15)

Evidentemente, trata-se, nessa diferenciação, de uma suposta tendência que teria que ser comprovada empiricamente, mesmo porque a escolha de um canal de "comunicação com o passado" também passa por uma série de manipulações. Nos dois casos, o receptor fica exposto às intervenções dos responsáveis pela comunicação, mas acreditamos que sua passividade, no segundo caso, seja maior que no primeiro. De todo modo, a procura de um portador qualquer como canal de acesso ao passado é, no fundo, motivada pela idéia de que a informação contida ou emitida por aquele meio possa apresentar - ou representar alguma verdade. Na Antigüidade, o poeta, através de sua palavra, servia de "guardião" e "censor" da memória. Ele elegia os acontecimentos que deveriam ser contados (descartando, censurando ou não lembrando de outros) que, com isso, ganhavam o status de verdades. No meio televisivo, o uso da imagem confere aos eventos "contados" uma maior veracidade, pois, a exemplo de um São Tomé, não apenas ouvimos, porém vemos. Mesmo sabendo de sua manipulação, a visualização dessas imagens nos dá uma sensação de estar assistindo ao acontecimento "em tempo real". 
O sentido da visão pode ser mais apurado e mais reconfortante. Mas a operação de lembrar, ou de resgatar um passado, constitui um paradoxo que os meios de massa, e principalmente a televisão, multiplicam infinitamente. Lembrar implica esquecer. Não podemos lembrar de tudo e, sempre que nos lembramos de alguma coisa, estamos esquecendo de outras. No caso da televisão, devido à sua dinâmica acelerada, como nos adverte Beatriz Sarlo em outro ensaio, essa relação lembrança/esquecimento é levada ao extremo. A autora aponta para a "rapidez com que as notícias se devoram umas às outras, enquanto a última novidade pisa o terreno ainda quente do fato que passará ao esquecimento (...)" (16).

Por outro lado, a oralidade, a coloquialidade e a linguagem imagética, predominantes nesse meio, parecem inverter a lógica tradicional dos discursos, pois disputam e dessacralizam um lugar de saber antes pertencente apenas à tradição letrada. Esse processo contribui para a aparência "caseira" da televisão. Ao lugar "sagrado" e "intocável" das instituições ela opõe sua "informalidade", sua "proximidade" e sua "eficiência" que, somadas à popularização e à difusão dos aparelhos, criam uma impressão democrática de igualdade. Diante da televisão, "somos todos iguais". As imagens que chegam à mansão da zona sul são as mesmas que chegam ao barraco da periferia, podendo haver diferenças apenas na qualidade de recepção dessas imagens. Aliás, há um dado curioso que poderia ser investigado mais a fundo: nas favelas, - número de aparelhos de televisão muitas vezes supera o número de bens tidos como essenciais. Seria exagerado dizer que a televisão se tornou o bem mais essencial da modernidade?

Beatriz sarlo nos ensaios $A$ democracia midiática e seus limites e sete hipóteses sobre a videopolitica aponta ainda outros aspectos relativos à impressão de democracia do meio televisivo.

No primeiro, a autora analisa o caso de uma batalha judicial entre um ex-casal de argentinos pela guarda da filha, para mostrar como a aparente proximidade, a familiaridade, a rapidez e a simplificação produzidas pela televisão abalam a legitimidade das instituições. No caso Oswald $X$ Wilner, a opinião pública argentina foi mobilizada e se mobilizou em nome do "direito natural" da mãe, contestando a decisão judicial de que a posse da criança deveria ser do pai. Segundo Sarlo

A esfera pública não é, então, apenas um lugar de onde se emite informação, nem onde se constrói opinião. Passou a ser também um lugar onde a opinião se contrapõe às instituições, disputando com elas a jurisdição para decidir sobre os conflitos privados que se transformam em públicos justamente para serem subtraídos das 
instituições (a justiça, neste caso) que os acolhem. A democracia de opinião se contrapõe à democracia das instituições; denuncia-se - caráter formalmente abstrato das instituições frente à diversidade concreta e humanizada da opinião que não pretende lidar com outras leis que não sejam as da natureza (...) (17)

Lembremos que a democracia de opinião é apenas ilusória. Ela corresponde, na verdade, ao que hoje chamamos, pejorativamente, de democratismo. Na televisão, o assunto privado é transformado em assunto público. A familiaridade gerada por este movimento permite que, diante do caso particular, o espectador comum se identifique e se sinta capaz e no direito de emitir seu juízo, muitas vezes sem saber que está sendo levado a isso. Afinal, o espaço para que expresse seu arbítrio é controlado (mediado), não dependendo de sua vontade e, sim, do interesse das emissoras.

O tempo acelerado e a "eficiência" da televisão se contrapõem à burocracia e à lentidão das instituições. Na tela, a solução de problemas complexos leva o tempo que duram os programas. Isso só é possível, porém, à custa de um "achatamento" e de uma "simplificação" dos temas apresentados, cujas resoluções levam em conta não valores universais e racionais e, sim, individuais e emocionais. Diante dos problemas das instituições, a democracia de opinião não apresenta um questionamento sério (o que seria ótimo), pois não propõe mudanças sociais, políticas ou institucionais. Ela apenas, tomando como exemplo o que fez Oswald,

desqualifica a justiça como caminho para a reparação dos males produzidos em sociedade: não quer modificações, mas exige uma solução favorável agora mesmo, com a qualidade da imediatez e com a irresponsabilidade quanto às conseqüências que também os meios, convertidos em baluarte da opinião, ostentam. (18)

As mudanças espaciais, temporais, valorativas e formais decorrentes da era eletrônica não poderiam deixar de refletir no campo político, como nos mostra Sarlo, no segundo ensaio. A televisão não é apenas um meio mais eficiente de vigilância e de aproximação das ações políticas, mas se torna um palco onde os políticos, agora atores (muitas vezes com status de artistas), encenam seus papéis e põem em prática suas ações, não mais políticas, mas, dramáticas, que, por sua vez, não seguem o critério da necessidade mas, sim, o da visibilidade. Sua elegibilidade não é mais medida por qualidades morais e políticas, mas por sua capacidade midiática: "Nunca a imagem física do político teve uma importância tão decisiva (...)" (19)

Ainda sobre essas mudanças, Sarlo observa que: 
A vídeopolítica desliza por um continuum cujo ponto nodal está fortemente fixado no presente. A videopolítica intensifica o presente bem como debilita o passado e o futuro. A continuidade do tempo (o tempo do projeto, da comunidade, da história) é representado como uma sucessão de intervenções num presente deslocado do fluxo denso da temporalidade: as coisas aparecem e desaparecem a um ritmo que é completamente midiático. (20)

Se essa hipótese sobre a videopolítica for verdadeira (e acreditamos que seja), caberia reafirmar que a fixação no presente não é uma característica apenas da videopolítica, mas do meio da qual ela se utiliza. Há bons motivos de ver a televisão como inimigo da memória. Se este meio, de alguma forma, não é capaz de servir de intermediação entre as instâncias do tempo, é de se perguntar se não perdeu parte de sua capacidade midiática. Nessa perspectiva, o paradoxo lembrar/esquecer, sobre o qual opera a televisão, se torna perigoso: "Nada existe se não aparece na tela, e ali nada dura muito tempo." (21) Cabe à modernidade buscar o equilíbrio entre a necessidade de sua mediação e a impossibilidade de se abdicar da memória.

$\mathrm{Na}$ verdade, o "inimigo" não é a televisão, pois nada impede que ela apresente filmes como Shoah. O problema é o imediatismo que prevalece nela, a transmissão das notícias do dia e de shows de diversão que, além de passarem por influências ideológicas mais ou menos subliminares, não se preocupam com a mediação entre as "ruínas" do presente como passado, nem identificam o presente como algo "arruinado".

Finalizando, gostaríamos de apenas apontar para outro aspecto da gravação enquanto "ponte" no tempo: ela não apenas garante, pela sua presença, a conservação de vestígios do passado, mas ela mesma tem um caráter histórico, fazendo uma ponte entre o momento de sua produção e a atualidade do leitor. Os nossos livros são sempre presentes nas nossas bibliotecas, garantindo a conservação dos textos do passado. Ao mesmo tempo, eles não passam de matéria morta enquanto sua presença é apenas virtual e enquanto o passado neles contido não passe pela atualização da leitura. De cada "médium" sempre saem duas pontes: além de fazer a ligação com o passado anterior a ele, há a ponte com o presente da recepção posterior a ele.

O livro não é um médium "ao vivo", não abre um canal imediato para outra esfera. Mas ele também não é um médium morto - se é que algo morto pode servir de médium. Como qualquer informação gravada, necessita da "vivificação", da "reanimação" para servir de médium. Ao contrário das transmissões de televisão ao vivo, que não apontam para outra coisa senão o "Aqui e agora" - não é à toa que um programa de televisão, de valor informativo mais que questionável, tem esse nome - o livro, assim como qualquer "gravação", transcende o momento, uma vez 
que exige do seu receptor uma participação ativa, uma "investigação" dos vestígios deixados.

Como procuramos mostrar através da comparação, proposta por Beatriz Sarlo, entre os filmes de Lanzmann e Spielberg sobre a mesma temática, a questão da participação do espectador, isto é, a questão da recepção não depende tanto do "médium", quanto de elementos estéticos. Além de poder apresentar os filmes mencionados - com as perdas associadas a uma tela muito mais reduzida - o conteúdo televisivo, mesmo numa programação ao vivo, pode variar entre a trivialidade do Faustão e suas "vídeo-cassetadas" e as discussões muitas vezes exigentes da Roda Viva, que interessam ao espectador "investigador".

O caso do livro não é muito diferente, pois ele tanto pode oferecer o sex \& crime conhecido como um certo gênero de cinema, quanto exigir do leitor que siga as "veredas" de um Guimarães Rosa. O texto pode tanto alimentar uma fantasia imediatista quanto o prazer de um certo suspense, seja ele de um romance policial, seja ele de outro gênero, pois qualquer palavra pode ser um vestígio, uma "promessa de felicidade", como dizia Adorno (citando Stendhal) para falar da arte em geral. E a arte da arte consiste em construir vestígios que, por natureza, prometem alguma coisa através de uma mediação às vezes um tanto circunstanciosa. Não importa o meio, o "médium" dessa mediação, mas a exigência que faz ao seu receptor. O problema, portanto, não é "a" televisão, mas o fato de sua programação atual prometer pouco além do sono de todos os dias.

\begin{abstract}
Starting form some fundamental reflexions about the concepts of "medium" and "recording", of the simultaneous communication "in space" and the successive communication "in time" and of orality and writing, the present text analyzes the ideas of Beatriz sarlo concerning books, movies e television as carriers of a different communicative aesthetics.
\end{abstract}

Key-words: Communication, recordin, aesthetics.

\title{
Notas
}

(1) Segundo informações do prof. Manfred Hanke da FAFICH-UFMG, não foi a intenção de Shannon e Weaver, considerados os fundadores da ciência da comunicação, fornecer um modelo de comunicação social, mas apenas de transmissão técnica de informações. Por isso, as críticas a esse modelo não atingem tanto os dois autores quanto a sua aplicação precipitada ao plano social.

(2) Cf. também os inevitáveis "vasos comunicantes" que, nos bons tempos da educação escolar, faziam parte das aulas de Física. 
(3) Esse é mais ou menos o teor do livro A Arte do Vídeo, de Arlindo Machado, que considera que uma transmissão seja mais verdadeira por estar ao vivo e, assim, menos sujeito às manipulações dos produtores (cf. pág. 67 s. .).

(4) Sobre a questão da materialidade da comunicação, inclusive a questão se e até que ponto esta materialidade influencia a qualidade da informação, cf. a coletânea Materialities of Communcation (v. Bibliografia).

(5) A tentativa de Arlindo Machado, no já mencionado livro, de valorizar a televisão (ao vivo) em detrimento do filme de cinema (gravado) se evidencia como pouco fecunda justamente pelo fato de ele não ter dado a devida importância ao fenômeno da gravação. Dando pouca importância ao fato de a televisão ser um meio de comunicação híbrido no sentido de transmitir tanto programas ao vivo quanto gravados - inclusive filmes de cinema -, a argumentação se perde em malabarismos pouco convincentes como aqueles em torno dos programas pré-gravados, supostamente contaminados pelos programas ao vivo (p. 81).

(6) O anglicismo "salvar" (um documento) acrescenta um toque dramático ao processo da gravação, pois aponta para o perigo da sua perda.

(7) Walter Benjamin, em "O Narrador", observa que a passagem de um tipo de comunicação a outro coincide com a substituição da narrativa oral pelo romance escrito, o que teria levado a um isolamento do indivíduo. Teria que diferenciar, portanto, entre a comunicação "viva", isto é, em grupos, e a comunicação "ao vivo" dos modernos meios eletrônicos, inclusive o chat, que, apesar de serem "ao vivo", não impediram tal isolamento. Segundo informações da psicóloga Rosa Hatz, há uma hipótese de esse isolamento ter contribuído para o aumento de depressões.

(8) Cf. a discussão jurídica em torno das gravações sonoras, isto é, se tais gravações podem ser consideradas como provas no tribunal.

(9) A história contra o esquecimento, p. 35-42. Não esquecer a guerra das Malvinas, p. 43-54.A democracia midiática e seus limites, p. 117-128. Sete hipóteses sobre a videopolítica, p. 129-140. [Esta citação se encontra especificamente na p.36].

(10) Beatriz SARLO p. 37-38; grifo nosso.

(11) Cf. também os protestos da comunidade judaica contra qualquer tentativa de mudança nos campos de concentração e até mesmo nos cemitérios destruídos pelos nazistas.

(12) Beatriz SARLO, p. 36.

(13) Beatriz SARLO, p. 52; grifo nosso.

(14) Lembramos que o próprio Kant, em sua Crítica da razão pura, apresenta a "coisa em si" como algo inacessível que se nos apresenta apenas como "fenômeno", ou seja, da maneira que nos aparece nos limites do tempo e do espaço. Aliás, o capítulo onde Kant trata dessas "formas de intuição" leva o título "Estética transcendental". (p. 61-87)

(15) Arlindo Machado afirma que, devido à sua baixa resolução (!), a televisão exigiria a colaboração ativa do espectador ( $\mathrm{p}$. 60), tendo, inclusive, uma "força política mobilizadora" (p. 97), o que evitaria "transes hipnóticos" - sendo que há pessoas que afirmam que a televisão, para eles, seria o melhor sonífero... 
(16) Beatriz SARLO, p.117.

(17) Beatriz SARLO, p. 124

(18) Beatriz SARLO, p. 126

(19) Beatriz SARLO, p. 132 .

(20) Beatriz SARLO, p. 135 .

(21) Beatriz SARLO, p. 137.

\section{Bibliografia}

BENJAMIN, Walter. O narrador. Considerações sobre a obra de Nikolai Leskov. in: Obras escolhidas. Vol. I. São Paulo: Brasiliense, 1985. p. 197-221.

Sobre o conceito de história." ["Teses"] in: Obras escolhidas. Vol. I. São Paulo: Brasiliense, 1985. p. 222-234.

KANT, Immanuel. Crítica da razão pura. Lisboa: Fundação Calouste Gulbenkian, 2a ed., 1989.

MACHADO, Arlindo: A arte do vídeo. São Paulo: Brasieliense, 3a ed., 1995. MATERIALITIES OF COMMUNICATION. Hans Ulrich Gumbrecht et al. (orgs.). Stanford University Press, 1994.

SARLO, Beatriz: Paisagens imaginárias. Intelectuais, arte e meios de comunicação. São Paulo: Edusp, 1997.

SHANNON, Claude; WEAVER, Warren. The Mathematical Theory of Communication. Univ. of Illinois Press, 1998. 